\title{
Approach toward molecular targeted therapy for cancer using microbial products
}

\author{
Masaya Imoto ${ }^{1}$
}

Received: 11 July 2021 / Revised: 15 July 2021 / Accepted: 15 July 2021 / Published online: 27 September 2021

(c) The Author(s), under exclusive licence to the Japan Antibiotics Research Association 2021

Despite dramatic progress in cancer research, cancer remains a major cause of death globally. Statistics provided by The International Agency for Research on Cancer, an external research organization of the World Health Organization, for 20 world regions suggested 18.1 million new cases of cancer and 9.6 million deaths due to cancer in 2018 [1].

On the other hand, the age-standardized rate of cancer mortality is declining because of advances in diagnostic technology and treatment methods in the West, Korea, and Japan (https://www-dep.iarc.fr/WHOdb/WHOdb.htm). One of the reasons for this is that cancer genome information has significantly increased the response rate of molecular targeted therapeutic agents for cancer.

Chemotherapy was introduced 70 years ago, but early anticancer drugs were cytotoxic compounds targeting fastgrowing cancer cells. Sarkomycin, isolated by Umezawa from the cultured broth of a Streptomyces strain in 1953, was the world's first antitumor drug [2]. Unfortunately, sarkomycin never reached clinical application, but since then cytotoxic antitumor drugs have been actively developed. Numerous studies on the discovery, structure determination, organic synthesis, and mode of action of cytotoxic antitumor drugs derived from microorganisms have been published in this journal.

Cytotoxic antitumor drugs exert their antitumor activity by inhibiting DNA synthesis and cell division in cancer cells. However, these mechanisms of action also act on normal cells. These drugs therefore have low selectivity for cancer cells, and their side effects on normal tissues were a major concern. The development of new types of anticancer agents was thus warranted.

\footnotetext{
Masaya Imoto

m.imoto.xz@juntendo.ac.jp

1 The journal of antibiotics https://www.nature.com/ja/
}

In the 1980s, oncogenes were cloned in a continuing series, and as molecular cell biology developed, the functions of oncogene products and their related signaltransduction pathways were elucidated. This led to the development of a new type of selective, less toxic antitumor drug, now referred to as molecular targeted therapeutic agents, targeting oncogenes or their associated signaling pathways. Notably, microbial secondary metabolites have again contributed significantly to the development of these drugs.

Many oncogenes possess tyrosine kinase activity, and inhibitors of this activity were therefore expected to form the basis of a new type of anticancer drug. In the mid-1980s, the tyrosine kinase inhibitors herbimycin A [3, 4], erbstatin $[5,6]$, and genistein [7] were discovered in Japan, ahead of the rest of the world. All of these compounds were isolated from cultured microbial broths. In response, various tyrosine kinase inhibitors were developed based on the structures of these compounds, and after that various improvements were made to these inhibitors $[8,9]$. As a result, as early as 2000 , the tyrosine kinase inhibitors imatinib (Gleevec) [10] and gefitinib (Iressa) [11] were clinically used as the first molecular targeted therapeutic agents.

The contribution of microbial secondary metabolites to the early stages of development of molecular targeted therapeutic drugs for cancer is not limited to tyrosine kinase inhibitors. For example, inhibitors of histone deacetylase (HDAC) are currently attracting attention as agents of epigenetic control, but pioneering research on HDAC inhibitors was conducted in the mid-1980s with trichostatin A. Trichostatin A was originally isolated from actinomycete cultured broth as antifungal antibiotics [12], Yoshida, later discovered its HDAC inhibitory activity [13, 14]. Vorinostat (Zolinza) [15], synthesized based on the structural characteristics of trichostatin A, was approved in the United States in 2006 for the treatment of skin and peripheral T-cell lymphoma. Romidepsin (Istodax) [16], which is currently used clinically, is another HDAC inhibitor that is produced by a microorganism. 
Another example of microbial secondary metabolites that contributed to molecular targeted therapy for cancer is proteasome inhibitors. The first reported proteasome inhibitor was the microbial secondary metabolite lactacystin [17]. Three types of proteasome inhibitor are currently used to treat multiple myeloma (for example, bortezomib [Velcade] [18]), and research using lactacystin conducted in the mid-1990s contributed significantly to the development of these drugs [19].

Since then, our increasing knowledge of the structural diversity and range of physiological activities of microbial secondary metabolites has greatly contributed to the development of molecular targeted therapeutic agents by providing information on target molecules and lead compounds.

This special issue compiles recent chemical biology research on microbial secondary metabolites that target the molecules and signal transduction systems responsible for tumor malignancy.

\section{Compliance with ethical standards}

Conflict of interest The author declares no competing interests.

Publisher's note Springer Nature remains neutral with regard to jurisdictional claims in published maps and institutional affiliations.

\section{References}

1. Bray F, Ferlay J, Soerjomataram I, Siegel RL, Torre LA, Jemal A. Global cancer statistics 2018: GLOBOCAN estimates of incidence and mortality worldwide for 36 cancers in 185 countries. CA Cancer J Clin. 2018;68:394-424.

2. Umezawa H, Takeuchi T, Nitta K, Yamamoto T, Yamaoka SS. An anti-tumor substance produced by streptomyces. J Antibiot (Tokyo). 1953;6:101

3. Uehara Y, Hori M, Takeuchi T, Umezawa H. Screening of agents which convert 'transformed morphology' of Rous sarcoma virusinfected rat kidney cells to 'normal morphology': identification of an active agent as herbimycin and its inhibition of intracellular src kinase. Jpn J cancer Res: Gann. 1985;76:672-5.

4. Uehara Y, Hori M, Takeuchi T, Umezawa H. Phenotypic change from transformed to normal induced by benzoquinonoid ansamycins accompanies inactivation of p60src in rat kidney cells infected with Rous sarcoma virus. Mol Cell Biol. 1986;6:2198-206.
5. Imoto M, Umezawa K, Isshiki K, Kunimoto S, Sawa T, Takeuchi $\mathrm{T}$, et al. Kinetic studies of tyrosine kinase inhibition by erbstatin. $\mathrm{J}$ Antibiot. 1987;40:1471-3.

6. Umezawa H, Imoto M, Sawa T, Isshiki K, Matsuda N, Uchida T, et al. Studies on a new epidermal growth factor-receptor kinase inhibitor, erbstatin, produced by MH435-hF3. J Antibiot. 1986;39:170-3.

7. Akiyama T, Ishida J, Nakagawa S, Ogawara H, Watanabe S, Itoh $\mathrm{N}$, et al. Genistein, a specific inhibitor of tyrosine-specific protein kinases. J Biol Chem. 1987;262:5592-5.

8. Levitzki A. Tyrphostins: tyrosine kinase blockers as novel antiproliferative agents and dissectors of signal transduction. FASEB J. 1992;6:3275-82.

9. Yaish P, Gazit A, Gilon C, Levitzki A. Blocking of EGFdependent cell proliferation by EGF receptor kinase inhibitors. Science. 1988;242:933-5.

10. Druker BJ, Tamura S, Buchdunger E, Ohno S, Segal GM, Fanning $S$, et al. Effects of a selective inhibitor of the Abl tyrosine kinase on the growth of Bcr-Abl positive cells. Nat Med. 1996;2:561-6.

11. Wakeling AE, Barker AJ, Davies DH, Brown DS, Green LR, Cartlidge SA, et al. Specific inhibition of epidermal growth factor receptor tyrosine kinase by 4 -anilinoquinazolines. Breast Cancer Res Treat. 1996;38:67-73.

12. Tsuji N, Kobayashi M, Nagashima K, Wakisaka Y, Koizumi K. A new antifungal antibiotic, trichostatin. J Antibiot. 1976;29:1-6.

13. Yoshida M, Beppu T. Reversible arrest of proliferation of rat $3 \mathrm{Y} 1$ fibroblasts in both the G1 and G2 phases by trichostatin A. Exp Cell Res. 1988;177:122-31.

14. Yoshida M, Kijima M, Akita M, Beppu T. Potent and specific inhibition of mammalian histone deacetylase both in vivo and in vitro by trichostatin A. J Biol Chem. 1990;265:17174-9.

15. Secrist JP, Zhou X, Richon VM. HDAC inhibitors for the treatment of cancer. Curr Opin Investig Drugs. 2003;4:1422-7.

16. Ueda H, Nakajima H, Hori Y, Fujita T, Nishimura M, Goto T, et al. FR901228, a novel antitumor bicyclic depsipeptide produced by Chromobacterium violaceum No. 968. I. Taxonomy, fermentation, isolation, physico-chemical and biological properties, and antitumor activity. J Antibiot. 1994;47:301-10.

17. Omura S, Fujimoto T, Otoguro K, Matsuzaki K, Moriguchi R, Tanaka H, et al. Lactacystin, a novel microbial metabolite, induces neuritogenesis of neuroblastoma cells. J Antibiot (Tokyo). 1991;44:113-6.

18. Teicher BA, Ara G, Herbst R, Palombella VJ, Adams J. The proteasome inhibitor PS-341 in cancer therapy. Clin Cancer Res. 1999;5:2638-45.

19. Fenteany G, Standaert RF, Lane WS, Choi S, Corey EJ, Schreiber SL. Inhibition of proteasome activities and subunit-specific amino-terminal threonine modification by lactacystin. Science. 1995;268:726-731. 